After this final selection, plants destined for an experiment are transferred to 6 -in. pots containing vermiculite, perlite or other suitablo medium. Nutrients are providod by frequent application of half-strength standard Hoagland solution. In practice, more than 60 per cent of treated plants are discarded as a result of selection for uniformity. In this laboratory, 600 cuttings are propagated each month to provide continuity of supply of experimental material.

It might be argued that the test-plants described hero are so unlike grape vines that their behaviour gives little indication of circumstances in the ficld. Experience so far does not support this criticism. Weaver et al.5,6 have shown that the kinin ' $S D 8339$ ', 6-(benzylamino)-9(2-tetrahydropyranyl)-9H purine, has marked effects in increasing fruit set and size in field vines, including the 'Black Corinth' (syn. 'Xante Currant'). Using test-plants of this variety, parallel effects of 'SD 8339 ' on fruiting have been observed. Those rosults suggest that testplants may be of particular value in the initial evaluation of offects of new growth substances on fruiting in vines.

I thank Dr. J. VanOverbeek for supplies of 'SD 8339'. M. G. Mulinins

C.S.I.R.O

Horticultural Research Section,

Adelaido, South Australia.

${ }^{1}$ Gates, C. T., Brouma, D., and Groenewegen, H., Austral. J. Agric. Res., 12, 1050 (1961)

${ }^{2}$ Alexander, D. McE., and Woodham, R. C., J. Hort. Sci., 38, 307 (1963).

"Alexander, D. McE., J. Hort. Sci. (in the press).

' Hale, C. R., and Weaver, R. J., Hilgardia, 33, 89 (1962).

${ }^{5}$ Weaver, lR. J., and VanOverbeck, J., Calif. Agric., 17, 12 (1963).

' Woaver, R. J., VanOverbeek, J., and Pool, R. M., Nature, 206, 952 (1965)

\section{Field Resistance in Lolium sp. to Leaf Rust (Puccinia coronata)}

A HIGH degree of 'field' resistanco to infection by leaf rust (Puccinia coronata var. lolii) has been developed in peronnial ryegrass (Lolium perenne), an open pollinated plant, by selecting individual plants for resistance (as one of several agronomic characters) from the progenies of open pollinated strains. The strains, sclected by Corkill et al., were tested for combining ability and other agronomic characters. Soveral were allowed to interpollinate to form the synthetic variety released as New Zealand perennial ryegrass ${ }^{1}$.

A high degree of heterozygosity has been maintained in this variety. Although leaf rust occurs on a few individual plants it can rarely be transferred to neighbouring plants even though these may be infected; this indicates that physiological races of the pathogen are present. Neither tho characteristics of the physiological races nor the genetic nature of the resistance against the pathogen are at present known. Resistance would appear to be due to an accumulation of genes within the variety but, because of the considerable and intentionally high degree of heterozygosity of individual plants, it seems probable that neighbouring plants are of different genotypos, and therefore owe their resistanco to leaf rust to various combinations of a multiplicity of different genes.

This resistance to many physiological races of a pathogen, termed 'horizontal resistance' by van der Plank2, though treated as a minor character by the plant breeders, was developed by brecding for 20 years a crop that previously had no noticeable resistance to the diseaso. A significant factor would appear to be that the breeding nursery was established in a locality which experiences severe natural infection of $P$. coronata var. lolii every sirmmer.

\section{J. G. GIBBs}

Department of Botany, Victoria University, Wellington, Now Zealand.

Corkill, L., Proc. Seventh Intern. Grasslands Congr., paper No. 39 (1056)

${ }^{3}$ Plank, J. F van der, Plant Diseases: Epidemics and Control (Aeademio Press, London, 1964).

\section{Effect of Plant Regulators on the Incorpora- tion of Phosphorus-32 into the Alcohol-soluble Fractions of Pea Seedlings}

'THs communication reports experiments which we have carried out to examino and to compare some of the relations of the quantitative changes that ensue in the alcohol-soluble phosphorus fractions of pea seedlings, which have been induced by the effect of uncoupling and growth-regulating substances. In the course of the experiments, the changes in pea seedlings, which were treated with uncoupling and growth-regulating compounds in vivo, were recorded by labelling the phosphorylated products with ${ }^{32} \mathrm{P}$-phosphate and paper chromatography.

If the uncoupling effect ensues, one may expect that the inorganic or the oster phosphate fractions accumulate and that the quantity of the nucleotides containing enorgyrich phosphate decreases. Therefore, the changes in the following phosphorus fractions were analysed by meas. uring thoir phosphorus-32 activity: (1) inorganie phosphate; (2) ester phosphate; (3) phosphate coupled to an indole skeleton; (4) nucleotid phosphate. The ester fraction contains hexose and pentose phosphates, glyceris acid phosphate, adenosine monophosphate and a few unknown compounds with low phosphorus-32 activity. The indole phosphate fraction is an unknown compound which reacts in a similar manner to indole, sugar and phosphete, and if labelled with phosphorus-32 it becomes radioactive. The nucleotide phosphate fraction contnins compounds which roact in a similar manner to purine, sugar and phosphate, and their $R_{F}$-values are identical with those of the nucleotide polyphosphates.

Before the experiments were carried out, the plants were placed for $2 \mathrm{~h}$ in Knop's solution, diluted ten-fold and then (during the exporiment) transferred into a solution containing ${ }^{82} \mathrm{P}$-labelled potassium dihydrogen phosphate and the regulator. The controls were initially placed in a similar Knop's solution. The experimental plants were kept in the dark at $22^{\circ} \mathrm{C}$ for $24 \mathrm{~h}$, and then the various phosphorus fractions were analysed by means of paper chromatography. Simultaneously, measurements were taken to determine the growth of the roots and shoots, and the c.p.m. and distribution of radioactivity established as a percentage of the total activity of the single phosphorus fractions.

The data in Table 1 reveal that the total activity is highest in the control plants, thus all three compounds applied decrease the amount of the soluble phosphorus compounds in the following order: DNP > SA > IAA. Similarly, all the substances examined decrease the incorporation of the phosphorus-32 into the nucleotide fraction. The proportion of the total impulses is as follows: the quantity of inorganic phosphorus-32 decreases in the sequence of $\mathrm{C}>\mathrm{IAA}>\mathrm{SA}>\mathrm{DNP}$; in the ester fraction the sequence is approximately the opposite--SA > DNP > IAA > C (C, control; SA, salicylic acid; DNP, 2,4-dinitrophenol; IAA, indolyl-3-acetic acid). The participation of the nucleotide fraction in the total activity is parallel to that of the inorganic fraction. It is present in tho highost porcentage in the control plant and decreases in the order IAA > SA > DNP. Tho activity of the fraction of indole-phosphate-32 is the highest from the point of view of both its total and percentile activity in the plants treated with IAA: the percentile ratio is IAA $>\mathrm{C}>\mathrm{SA}>$ DNP; however, the difference between the c.p.m. and the percentile values is not significant.

Among the results, the most characteristio is the decrease which ensuos in the phosphorus-32 activity of the nuoleotide fraction in plants treated with regulators. This effect is greatest if typical uncoupling substances aro applied, but it may also bo observed in the case of IAA. The porcentile increase of the ester fraction activity and the simultaneous decrease of the activity of the nucleotide phosphate fraction are striking. 